\title{
İngiliz İtilaf Komiseri RAWLINSON'UN GÖZÜYLE MÜTAREKE DÖNEMINDE DOĞU ANADOLU VE KAFKASYA
}

\author{
Yrd. Doç. Dr. Rahmi DOĞANAY*
}

Albay Alfred Rawlinson İngiliz Hava Kuvvetlerinde görev yapmakteyken sağlık sebeplerinden dolayı kara sınıfına ayrılmış bir istihbarat subayıdır.

Birinci Dünya Savaşı'nda görev almış ve 1918 Nisanı'nda İran'da görevlendirilmiştir ${ }^{1}$. Bir müddet burada görev yapan Rawlinson, Londra'ya dönüşünden hemen sonra, 15 Şubat 1919'da Sir George Milne'in teklifiyle Selanik Seferi Kuvvetleri Genelkurmay İstihbaratına bağlı özel servis subaylığı görevine atanır ve 1 Mart 1919 'da Selanik üzerinden İstanbul'a ulaşır ${ }^{2}$.

* Fırat Üniversitesi, Fen-Edebiyat Fakültesi, Tarih Bölümü.

1. Lord Curzon'un kardeşi [bkz. Kazım Karabekir. İstiklal Harbimiz, İstanbul 1988, s. 983] veya yeğeni [bkz. Gotthard Jaeschke, Kurtuluş savaşı ile ilgili İngiliz Belgeleri, Ankara 1986, s. 148] olarak gösterilen Rawlinson. İngiliz yönetici elitinde yer alan ailelerden birisine menup olup, kardeşi Lord Rawlinson da Hindistan genel valiliği ve Arkanjel Ingiliz Birlikleri komutanlığı yapmıștır. Birinci Cihan Savașı'nın sonlarına doğru atandığı İran'da, bölgenin siyasi, sosyal ve iktisadi özellikleriyle ilgili bilgiler verir. O'na göre, Kafkasya'ya giren İngiliz birlikleri Bolşevik Ermeni yönetimi tarafından yardıma çağrılmıştır. Dolayısıyla İngiltere bir yandan Bolşevik Rusya'yı boğmaya çalışırken, diğer yandan Bolşevik Ermenilere yardım etmektedir. Bkz. A. Rawlinson, Adventure in The Near East, London 1923, s. 76 vd.

2. Rawlinson bu görevlendirmeyi, "Arkanjel'deki kuvvetlerimizin tahliyesi sorumluluğunu yüklenmeden önce kısa bir süre için Londra'ya gelmiş olan kardeşimle (Lord Rawlinson) kahvaltı ederken müstakbel şefim Selanik Seferi Kuvvetleri Başkomutanı Sir George Milne ile tanıştım. İstanbul'a nakledilmekte olan bu kuvvetler Hazar Denizi'ni aşıp, Bakü'ye gelecekler ve Kafkaslardaki diğer kuvvetlerle birlikte harekat yapan Kuzey İran ordularına katılacaklardı. Sir George, adı geçen yerleri bildiğimi işitince oraya gidip gitmeyeceğimi sordu. Memnuniyetle kabul edince bana özel bir görev verilmesini sağlad." demektedir. Bkz. A Rawlinson, a.g.e., s. 123. 
İngiliz İtilaf Komiseri A. Rawlinson'a Paris Barış Konferansı kararları doğrultusunda, Doğu Anadolu'da gerekli soruşturmaları yapmak ve denetlemelerde bulunmak görevi verilmişti ${ }^{3}$. Bunu yerine getirirken İngiltere'nin Kafkasya'daki istihbarat sorumlusu General Beach'e tabi olacak ve hazırlayacağı raporlar dıșında ${ }^{4}$, Batum'da kendisine tahsis edilecek iki otomobille, toplayacağ silahları kontrol altına alacaktı. Amiri konumundaki Beach ile İran'dan tanışmakta ve O'nun bölgede İngiliz istihbaratının yetersizliği yolundaki kanaatini de paylaşmaktadır. Onun için Beach'in istihbaratı genişletmesi ve güçlendirmesi, yönündeki isteğini memnuniyetle karşılayarak, bu görevi kendisi için en uygun ve "alışık olduğu" bir iş şeklinde mütalaa etmektedir ${ }^{5}$.

İstanbul'dan Tiflis'e gitmek üzere görevlendirilen A. Rawlinson, 5 Mart'ta buradan hareketle Varna üzerinden 9 Mart'ta Samsun'a, bir gün sonra da Batum'a vardı. Mart ayı sonuna kadar Tiflis, Tebriz, Bakü, Kars bölgelerinde yaptığı incelemeleri tamamlayarak 3 Nisan'da Batum'dan hareketle Trabzon üzerinden 22 Nisan'da Erzurum'a ulaşt ${ }^{6}$. 3 Haziran 1919'a kadar Kars ve Erzurum yöresinde incelemelerde bulunan bu İngiliz subayı, ilk elden bilgi alış verişi için 7 Temmuz'da Trabzon'a ve oradan da Batum'a gitti. 6 Ağustos'ta maiyetindekilerin çoğunu Türkiye diş1na gönderdikten sonra, 12 Ağustos'ta da kendisi İstanbul'a dönmek üzere hareket etti. İstanbul'a geldikten iki gün sonra hareketle Bulgaristan, Romanya ve Fransa üzerinden Londra'ya ulaşan Rawlinson, 20 Ekim'e ka-

3. Seçil Akgün, General Harbord'un Anadolu Gezisi ve Ermeni Meselesine Dair Raporu, İstanbul 1981, s. 53, Esasen Rawlinson'a göre de Mondros Mütarekesi, Müttefiklerin Türklere bir cemilesi olup, buna ne kadar uyulduğunu teftiş ve denetleme görevi kendisine verilmiştir. Sultan'ın bir yazısı (Rawlinson'a göre itimatname) ve Harbiye Nezareti'nin izin belgesi de bunu teyid etmektedir. Bkz. A. Rawlinson, a.g.e., s. 167

4. Gerçekten de Rawlinson'a Batum'da iki Ford otomobil tahsis edilmiştir. Bkz. A. Rawlinson, a.g.e., s. 134.

5. Bkz. A. Rawlinson, a.g.e., s. $140 \mathrm{vd}$.

6. Mondros Mütarekesi gereğince Türk ordularının 1878 sınırına çekilmesi işi. 1919 baharında henüz tamamlanamamıştır. Kars yöresinde bulunan IX. Ordu Komutanı Yakup Şevki Paşa buralara İngilizlerin gelmesine, Türk ordusunun silah, mühimmat ve iaşesine Ruslardan kaldığı gerekçesiyle el koyar endişesiyle karşı çıkmıştır. Gerçi Rawlinson Erzurum'a gelirken Yakup Şevki Paşa da ordusu lağvedilerek İstanbul'a çağrılmıştır. Ancak, Ordunun çekilmekte olduğu bu bölgelerde milis kuvvetleri oluşturulmuş ve yabancı müdahalelerine karşı mücadeleye devam etmektedir [Bkz. Birinci Dünya Harbinde Türk Harbi, Kafkas Cephesi, Ankara 1993, s. 780]. Bu sebeple Rawlinson Trabzon üzerinden Erzurum'a gitmeyi tercih ediyor. Yakup Şevki Paşa İstanbul'a giderken, Erzurum'a gelmekte olan Rawlinson ile Gümüşhane'de karşılaşırlar. Bkz. A. Rawlinson, a.g.e., s. 170. 
dar İngiltere'de kalmış ve 2 Kasım'da İstanbul'a, 26 Aralık'ta da tekrar Erzurum'a gelmiştir. Bu arada gezip gördüğü yerler hakkında müşahadelerini kaydeden 7 İtilaf Komiseri, İstanbul'un işgali üzerine tutuklanmış ve mübadele edildiği 1 Kasım 1921 tarihinde serbest bırakıldıktan ${ }^{8}$ sonra döndüğü İngiltere' de notlarını bir hatırat şeklinde düzenlemiştir ${ }^{9}$. Burada zaman zaman olaylar kronoloji bakımından karıştırılsa da verilen bilgiler Türk kaynaklarınca da teyid edilir mahiyettedir.

Rawlinson, İstanbul'un en çok Beyoğlu semtini beğenmekte ve burasını, "eski İstanbul, halis Türk şehri” olarak tanımlamaktadır. Mütareke dönemi İstanbul'unu, her türlü üniformanın görüldüŭüu, Rum ve Avrupalıların sivil çoğunluğu oluşturduğu, Türklerin pek ortalıkta görülmedi bir şehir olarak tasvir eder ${ }^{10}$. Batum'la ilgili değerlendirmeleri de; "Batum, Kafkaslarda iki tümeni bulunan İngiliz kuvvetlerinin üssüdür. Bakü'den boru hattı ile petrol gelmektedir. Türk ve İran sinırlarına kadar uzanan Bakü-Moskova-Tiflis Rus demiryolunun son noktası da burasıdır." şeklindedir. Yöredeki Rum halkın Türklerden çok korktuğunu ve birkaç kişiden ibaret de olsa İngiliz askerinin gelmiş olmasının bölgedeki Hıristiyanları rahatlattığını söyler ${ }^{11}$.

Devrik Rus Çarı'nın özel treninin tahsis edildiği İngiliz genelkurmay Başkanı Corry 12 ile birlikte geldiği Tiflis'i, muntazam yolları, elektrik ay-

7. Rawlinson'un bir kısım askeri, siyasi ve sosyal alandaki tespitleri ile bazı şahıs ve topluluklarla ilgili kanaatleri oldukça ilginçtir. Bazen oldukça teferruatlı bir şekilde ifade edilen bu tespitlerde özgün gözlemlere de rastlanmaktadır. Mesela Rawlinson geldiğinde 7 yıldır Türk hakimiyetinden çıkmış olan Selanik ile ilgili olarak; "şehrin yıkılmamış bölgelerinde her 90 metrede bir cami bulunmakta" şeklindeki ifadeler buna örnektir. Bkz. A. Rawlinson, a.g.e., s. 128.

8. Rawlinson, 16 Mart 1920 'de İstanbul'un işgali üzerine evinde gözaltına alınmış ve 1 Şubat 1921 'de genel hapishaneye nakledilmiştir. Londro Konferansı çerçevesinde yapılan Türk-İngiliz ikili görüşmelerinde Rawlinson ile Malta'daki Türk esirlerin mübadelesi söz konusu olmuş, Rawlinson mübadele için 28 Mart'ta Trabzon'a götürülmüş, bu konuda çıkan anlaşmazlık üzerine 24 Nisan'da yeniden Erzurum'a getirilmiştir. 5 Ekim'de mübadele için yeniden hareketle 14 Ekim'de Trabzon ve 31 Ekim'de İnebolu'ya götürülen Rawlinson, 1 Kasım 1921'de mübadele edilerek serbest kalmıştır.

9. İstihbaratçıların çalışmalarından hemen sonra hatıralarını yayınlaması, günümüzde olduğu gibi o dönemde de alıșılmadık bir durumdur. Ancak, Rawlinson'un hatıralarına İngiliz yöneticilerinin büyük değer ve destek verdikleri görülmektedir ki, I. Bölümün takdimini General Dunsterville, II. Bölümün takdimini George Milne yazmışlardır. Bkz. A. Rawlinson, a.g.e.

10. Bkz. A. Rawlinson, a.g.e., s. 131

11. Bkz. A. Rawlinson, a.g.e., s. 139

12. 23 Mart'ta Tiflis'e hareket eden General Corry, Bakü, Hazar ve Merv bölgesini teftiş edecektir. Maiyetinde Fransa'da V. Orduya komuta eden ve sivil bir görevle 
dınlatması, tramvayları, güzel otelleri, bir opera binası ve eski kral saraylarıyla bir Avrupa şehri olarak tanımlar. Rawlinson'un ifadesiyle, Tiflis'teki halk da Mezopotamya'da gördüğü gibi kırma bir kalabalıktı. Ancak Kafkaslarda Türkler fazlayd ${ }_{1}{ }^{13}$. Bölgede Rusların da fazla miktarda bulunduğunu kaydeden Rawlinson, Ruslara karşı Gürcü, Osetin, Avar, İnguş ve Kafkasların kuzeyinde yaşayan vahşi kabilelerin o anda ezici çoğunluğu oluşturduğunu düşünmektedir. Rawlinson, Amerikan Yakın Doğu Yardım Teşkilatının çalışmalarına da burada şahit olmuş ve onların yardımlarından hayranlıkla bahsetmiştir. Batum'a gelen Amerikan gemilerinin taşıdığ 1 yiyecekler Batum, Tiflis, Kars, Erivan ve bölgelerinde açlık çeken Hıristiyanlara dağıtılmaktadır ${ }^{14}$. Esasen bu yardım malzemelerinin tam bir dökümünü de başka bir kaynaktan tespit edebilmekteyiz ki, bunlar arasında şişe sütler, dikiş makineleri yanında, 78 röntgen makinesinin bulunması dikkat çekicidir'15. Rawlinson, bu yardımların bölge halkında Amerika'ya olan ilgili arttırdığı ve onların bu ülkeye karşı şükran duygularıyla dolu olduklarını özellikle vurgular.

$\mathrm{Bu}$ arada, birlikte yolculuk ettiği İngiliz yetkililerinin ortak görüşünü de tespit eden Rawlinson'a göre; hükümetlerinin politikasındaki belirsizlik, Kafkaslarda muhtelif ırklar arasındaki siyasi ikbal çatışmalarını cesaretlendirecek boyuttadır ${ }^{16}$. Rawlinson Tiflis'te 14 kişilik ekibini oluşturarak onları kendi istekleri doğrultusunda eğitir. Yalnız, yaver, tercü-

Bakü'de görevlendirilen Sir Hubert Gough da bulunmaktadır. Bkz. A. Rawlinson, a.g.e., s. 141.

13. Rawlinson hatıratının bu bölümünde Orta Asyalı Tatarlardan bahseder [Bkz. A. Rawlinson, a.g.e., s. 145]. Daha başka bölümlerde de Türklerin yanında Tatarlardan hatta Alevileri ifade etmek üzere de "Türkmen" tabirini kullanır. Bu tabir "Türkomen/Kars bölgesinde Alevi Türkler şeklinde anlamak mümkün ise de eserde sömürgeci bir istihbarat subayının yaklaşımı olarak da düşünebiliriz.

14. Bkz. A. Rawlinson, a.g.e., s. 145.

15. Bu yardımlar, 1919 Şubatı'nda söz konusu Amerikan kurumunun organizasyonu ve Türkiye'deki temsilcileri James L. Barton ve Peet Haskell marifetiyle, ilk partide 2 bin ton un, 2500 konserve, 800 hastane elbisesi, 200 varil petrol, 500 şişe süt, 18 yük arabası, 20 ambulans, 50 bin battaniye, 1.575 bin metre kumaş, 26 çadır, 78 röntgen makinesi ve 200 ton kömür, ikinci partide de 5 bin tondan fazla un, 50 dikiş makinesi, bin şişe süt, bir hastahane ünitesi, 5 bin çift ayakkabı bölgeye ulaştırılmıştı. Daha sonra da 30 doktor ve 60 hemşirenin de dahil bulunduğu 240 kişilik ekip misyona katılmak üzere yola çıkmıştı. Bkz. Joseph L. Grabill, Protestant Diplomacy and Near East, Minneapolis, 1971, s. 165 vd.

16. Bkz. A. Rawlinson, a.g.e., s. 140. 
man, şoför, aşçı, seyis ve emir erinden oluşan bu ekip içerisinde durumu resmi sıfatına en uygun olan tercümandır ${ }^{17}$.

İngiliz İtilaf Komiserine verilen görevin mahiyeti açık olmakla beraber, O tercihini Sosyalist Gürcistan Cumhuriyeti ile Azerbaycan arasındaki ilişkileri tespit ve tahlil etme yönünde kullanır. Bu eski ülkelerde ortaya çıkan yeni gelişmeler, nasıl bir politika takip edilebileceği hakkında merak uyandırmış olmalı ki; maiyetinden sadece şoförü ile tercümanını alan Rawlinson, Bakü'ye bir yolculuk düzenler18. Ancak, Bakü izlenimlerinden bahsetmediği gibi, ortaya ulaşıp ulaşmadığı da bilinmemektedir. Belki de yarı yoldan Tiflis'e dönmüştür. Tam bu sırada 20 Mart 1919 tarihinde gelen bir tel emriyle, Yakup Şevki Paşa'nın zorluk çıkardığ derek durumu inceleyip rapor vermesi istenince, Tiflis'ten hareketle maiyetindeki 8 kişi ile birlikte 23 Mart'ta Gümrü'ye ulaşan Rawlinson burasını, iddiasız bir şehir olarak tanımlar. O'na göre; "nüfusun yarıya yakınını Ruslar, diğer kısmını da aç, susuz, çıplak Ermeniler oluşturmaktadır. $\mathrm{Bu}$ ahali, varlığını Amerikan Yakın Doğu Yardım Teşkilatı'na borçludur". Gümrü'de hiç durmadan Kars'a geçen İngiliz İtilaf Komiseri, burada da rastladığı Ermenileri, Trabzon ve civarında gördüğü Hıristiyan Rumlara benzeterek, vaziyetlerini oldukça dramatik bir şekilde dile getirir $^{19}$.

Kars'ta nüfusun büyük çoğunluğunu Türklerin oluşturduğuna işaret eden Rawlinson, Amerikalıların yardımlarıyla ayakta duran bir miktar Ermeni'nin de varlığını belirtir. O'na göre; Amerikan Yardım Kurumu olmasa Ermeniler Kars bölgesini işgal edemezdi ${ }^{20}$. Bu konuda İngilizlerin

17. Bkz. A. Rawlinson, a.g.e., s. 142.

18. Bkz. A. Rawlinson, a.g.e., s. 143. Rawlinson'un, Azerbaycan'dan General Denikin kuvvetlerinin Kafkasya'daki faaliyetlerini incelemek ve bu birliklerle ilişki kurarak bilgi sahibi olmak istediği anlaşılmaktadır. Ama Gürcü sınırını geçtikten sonra Lars köyünde akbabaların ağaçlara asılı cesetleri yemekte olduğundan ve birkaç insan kılıklı sefil mahluğun Denikin'in öncüleri olduklarını söylediklerinden bahisle, bunların Denikin ile alakası olmayan disiplinsiz, zorbalık ve cinayetle geçinen bir güruh olduğunu tespit eder. Biraz ilerde çevre aşiretlerle birlikte bunlara direnebilen İnguş köylülerini de buna şahit gösterir. Herhalde güvenliğin olmayışı İngiliz İtilaf Komiserini geri dönmeye zorlamış olmalı. Bkz. A. Rawlinson, a.g.e., s. 151 .

19. Kars'tan Tiflis'e gitmekte olan Rawlinson, Gümrü dışında bazı Türk birliklerinin Ermeni sınırına doğru ilerlemekte olduğunu ve Ermeni muhacirlerin de Amerikan yardımından faydalanmak için Aras kıyısında toplandıklarını kaydeder. Bkz. A. Rawlinson, a.g.e., s. 161

20. Rawlinson'un da gayet yerinde tespit ettiği gibi Ermenilerin ileri harekatında Amerikalıların rolü için bkz. J. Grabill, a.g.e., s. 215-268. 
askeri müdahalelerinin rolünden hiç bahsetmez. Dolayısıyla bu yardımların Ermeniler nezdinde Amerika'ya itibar kazandırdığını vurgulayan İngiliz İtilaf Komiseri, yardımlardan hiç istifade edemeyen, esasen buna tenezzül de etmeyerek çok sefil duruma gelmiş olan Türk ahalinin nezdinde bu yardımların, Hilal ile Haç arasındaki çekişmenin bir delili olarak görüldüğü ve iki toplum arasındaki düşmanlığı arttırdığı kanaatini belirtir. Rawlinson bu tespitinde hiç de haksız değildir. Zira, savaştan önce 10 bin civarında nüfusa sahipo lan Kağızman, bu yardımlar sayesinde sadece 400 kişilik pespaye vaziyetteki bir Ermeni alayı tarafından işgal edilmiş ve şehrin nüfusu, Rawlinson buraya geldiğinde bin kişi civarına düşmüştü. Rawlinson Kağızman'da gördüklerinden sonra; "Müttefikler Kars'ın Ermenilere verileceğini ilan edince Ermeniler Kağızman'a üşüşerek zaptettiler. Birçok evlere ve Ruslara ait mülklere yerleştiler."'21 ifadesini kullanmaktadır. Ancak Ermenilerin 400 askerle zaptettikleri şehri kontrol edebildiklerini ve şehrin hemen dışından itibaren silahlı aşiretlerin hakim olduğunu kaydeder ${ }^{22}$. İngiliz İtilaf Komiseri yol üzerinde kendilerini resmi törenle karşılayan "bir Ermeni süvari alayı müsveddesini" denetleyip, Kağızman yolunda kendilerine bu alaydan atlı bir kafile refaket eder. Rawlinson, Aras vadisinde görüldüğü Hüseyin Bey liderliğindeki aşiret ile bu Ermenilerin durumunu karşılaştırıp, tepeleri tırmanırken düştükleri durumun kendilerine gülünç geldiği ve bu aşiretlerin savaşçılığı karşısında Ermenilerin hiç şanslarının olmadığı kanaatini belirtir ${ }^{23}$.

A. Rawlinson'a göre; Türkler çekilirken, "Kars’ta Türklerin bağımsız bir cumhuriyet kurmaları yönünde buradaki siyasi kargaşalıkları desteklediler. İngilizler bu kargaşayı durdurmak için buraya geldi. Çünkü bu bölge bir İslam Cumhuriyeti olursa Türkiye'den tarafa tavır koyacaktır".

21. Bkz. A. Rawlinson, a.g.e., s. 210.

22. Bkz. A. Rawlinson, a.g.e., s. 206. Rawlinson Kağızman'Mda sözde vali ve bir başpapaz tarafından resmi törenle karşılanmış ve Ermeniler tarafından tuz, ekmek ikram edilmiştir. Rawlinson'un ifadesiyle kendisini karşılayanların "kılıkları şaşkınlık verecek durumdadır. Kılıklarına bakıp gülmemekte zorlanırlar. Ekselans Vali eskiden beyaz ama şimdi beyazdan başka her rengi barındıran bir fanila pantolon giymiştir. Düğmeleri yoktur. Vaktiyle firak olan bir ceket giymiştir. İçinde başka bir şey yoktur ve valinin resmi kıyafeti bu iki parçadan başka bir şapka ile tamamlanmaktadır. Kılığı ve kıyafetleri ile Rawlinson ve adamlarına Charlie Chaplen'i hatırlatmıştır. Rawlinson, "gözlerimizden (gülmekten) gelen yaşları etrafımızdakiler bizim hiç anlamadığımız, fakat yürekler parçalayıcı acıklı hikayeye bağlıyorlardı." diyor [Bkz. A. Rawlinson, a.g.e., s. 209]. İngiliz bu durumun sorumlularını düşünse belki bu kadar eğlenemeyecekti.

23. Bkz. A. Rawlinson, a.g.e., s. $200 \mathrm{vd}$. 
$\mathrm{Bu}$ ifadeler, İngiltere'nin gerçek niyetini ortaya koymaktadır. Rawlinson bu konuyla ilgili İngiliz politikasını da eleştirmekten geri kalmaz. Zira İngiltere'deki yöneticiler Avrupa'daki Yüksek Konsey'e, Kars'ın Ermenilere verilmesi gerektiğini ve bunu gerçekleştirmeki çin bölgeye İngiliz kuvvetlerinin gönderileceğini bildirmișlerdir. Bu, Yüksek Konsey'in düștüğü pek çok hatadan birini teşkil eder. Bunun gerçekleștirilmesi Avrupalı güçlerin sevk edeceği önemli miktarda birliklerle mümkündü. Hatta, bölgeye kolayca ulaşacak birlikler varken, kısa bir süre önce bunların geri çekilmesi kararlaştırılmışt ${ }^{24}$. Ayrıca Rawlinson, Kars'ın Ermenilere verilmesi teklifinin bölgedeki Türk halkın silahlanmasına ve örgütlenmesine sebep olduğunu, dolayısıyla Türk ve Alman subayların nezaretinde eğitim yapan ahalinin ve İngiliz askerlerinin himayesinin ulaşamadığı yerlerde Ermenilerin varlığını tehlikeye soktuğunu vurgulamıştır. Bundan, Avrupalıların bölgedeki huzurun bozulmasına sebep olduğu gibi, Ermenileri de koruyamadıkları sonucu çıkmaktadır. Yalnız daha sonra Alman subayların bölgede eğitim verdikleri yönündeki iddiasını doğrulayacak herhangi bir delil de sunulamamaktadır.

Rawlinson, Kars'ta kurulan Şura Hükümeti'ne de atıf yaparak, Türk halkın Wilson Prensipleri'ne sarıldığını, Müslümanların topraklarının Ermenilere verilmek istenmesi karşısındaki tepkilerine saygı duyulması gerektiğini vurguluyor ve Türklerin Ermenilere duyduğu nefret bir tarafa, Ermenilerin Avrupalılardan yardım görmeden Türklere hükmedemeyeceği ve onları kontrol edemeyeceği gerçeğini kesin olarak ifade ediyor. Bu konuda sadece emirlere uymak adına ve kerhen çalıştı̆̆ dir ${ }^{25}$. Ancak Türk sempatizanı sayılamayacak İngiliz İtilaf Komiseri'nin uyarıları da yetkililer nezdinde dikkate alınmamıștır. Rawlinson bu imkansızlığın kendince gerekçelerini de göstermekteydi.

Kars'tan Batum'a ulaştığı anlaşılan Rawlinson, burada 2 Nisan 1919 tarihinde General Thomson ile görüşerek Kars'a takviye yapılmasını sağ$\operatorname{lar}^{26}$. Sonra deniz yoluyla Trabzon'a geçerek Osmanlı ordusunun terhis işlemleri ile silah ve cephane durumunu inceler. Nihayet 22 Nisan'da Erzu-

24. Bkz. A. Rawlinson, a.g.e., s. 153.

25. Bkz. A. Rawlinson, a.g.e., s. 153. Rawlinson'un görüşleri, bin yıldır Türklerin egemenliğinde bulunan bölgede başka bir unsur müdahalesinin getireceği büyük tepkiyi belirtiyordu. Bkz. Cevat Dursunoğlu, Milli Mücadele'de Erzurum, Ankara, 1946, s. 71 .

26. Bkz. A. Rawlinson, a.g.e., s. 161 
rum'a ulaşan Rawlinson maiyetiyle birlikte şehrin eski Ermeni mahallesinde ${ }^{27}$ Amerikalılara ait bir eve yerleştirilmiştir ${ }^{28}$.

23 Nisan 1919'da vali ve karargah geçici komutanı Albay Rüşdü'yü ziyaret eden Rawlinson, itimatnamesini göstererek, bütün silah ve mühimmat depolarını, yoklama cetvelleri ve bordroları inceleme yetkisi alır. Bu yolda çalışmalar yapar. 27 Nisan'da Kars'ta Başkomutanla görüşerek raporunu sunar. Başkomutandan tekrar Erzurum'a dönüp, teftiş işini tamamlamak ve silahları toplayıp memleket dışına çıkarmak görevini alır ${ }^{29}$.

Rawlinson, Türklerin gelecekteki niyetleri hakkında tahminlerin burada alacakları sonuçlara bağlı olduğu kanaatindedir ve görevlerinin çok önemli olduğunun farkındadır. Teftiş konusunda her türlü kolaylığın gösterilmesine rağmen, silahsızlanma konusunda işlerin savsaklandığını düşünmektedir ve bunu amirlerine bildirir. Kendilerinden kısa bir süre sonra da Kazım Karebekir Erzurum'a gelir ${ }^{30}$. Rawlinson Erzurum depolarını

27. Erzurum'da müstakil bir Ermeni mahallesi bulunmamaktadır. O dönemde yalnız bu cemaatin çoğunlukla yaşadığı yerler hakkında Bkz. Zeki Başar, "Öncesi ve Sonrasıyla Erzurum'un Kurtuluşu", ayrıca "Geçmişi unutan Ermeniler" ve Kazım Karabekir, "Erzurum'un Kurtuluşu” Ermeniler Hakkında Makaleler Derlemeler, Ankara 1982 ve Ahmet Refik, İki Komite, İki Kıtal, İstanbul 1919, s. 43.

28. Bkz. A. Rawlinson, a.g.e., s. 178. İngiliz İtilaf Komiserine göre, Ermeni mahallesindeki evlerin hepsi tahrip edilmiş sadece bu ev Amerikalılara ait olduğu için kurtulabilmiştir. Ancak, Rawlinson'dan yaklaşık üç ay sonra Erzurum'a gelen ve Ermenilerin durumunu inceleyen Amerikan Heyeti'nin böyle bir şeyden hiç bahsetmemesi dikkat çekicidir. Harbord başkanlığındaki bu heyetin faaliyetleri hakkında bkz. S. Akgün, a.g.e.

29. Bkz. A. Rawlinson, a.g.e., s. $175 \mathrm{vd}$.

30. Bu arada 3 Nisan $1919^{\circ}$ da Harbiye Nezareti emriyle XV. Kolordu Komutanlığına tayin edilen Kazım Karabekir, 13 Nisan'da İstanbul'dan hareketle Trabzon'a gidip 30 Nisan'a kadar burada birtakım çalışmalar yaptıktan sonra 3 Mayıs'ta Erzurum'a ulaşmıştır. Rawlinson'un bahsettiği Amerikalı yardımseverlerle $\mathrm{O}$ da yolda karşılaşmış, onlara otomobilleri için benzin vermiştir. Ayrıca, bölgedeki Hıristiyan halkın açlık ve perişanlığını her fırsatta gündeme getiren Rawlinson'un, hiç bahsetmediği Müslümanların durumunu da Karabekir tasvir eder. Mayıs başında Karabekir ile görüşen Rawlinson O'na takdirkar iltifatlarda bulunur [Bkz. Kazım Karabekir, İstiklal Harbimiz, İstanbul 1988, s. 17-22]. Karabekir Rawlinson'a yetimler için kurduğu okulu da gezdirir. Rawlinson buradaki çalışmalardan oldukça etkilenir. Hayranlık ve takdir duygularıyla dolu değerlendirmesi şöyledir: "Bunlar aynı zamanda çok sıkı askeri bir disiplin altında yetiştiriliyordu. Bütün askeri görevleri, modern silahların kullanılmasını öğreniyorlardı... Eğer bu bütün Türkiye’de yapılıyorsa, cesaret ve mukavemet gibi Allah vergisi vasıflara sahip Türk'ün hem Doğu'da hem Batı'da değilse bile, Doğu'da mutlaka bir kuvvet olacağını ve savaş sonrası konferansında Avrupa devletlerinin şimdiye kadar kabul ettikleri hattı hareketten çok daha farklı 
hızla denetlerken, geçitlerin kapalı olması ve kar yüzünden doğu sınırındaki işlerin yürümediğinden şikayetçidir. Erzurum depolarında bulduğu silahların sayısını veren Rawlinson, her tümen için 15 bin tüfek bırakma, yani Türk ordusunu silahsızlandırma uygulamasını da "çok keyfi bir muamele" ${ }_{31}$ olarak değerlendirir ve kendisinin bu işi sadece bir emir telakki ettiğini ifade ederken, vicdani açıdan rahatsızlığını açığa vurur.

Mayıs ayı boyunca gözlediği birtakım gelişmeler ve işlerin istediği süratte yürümemesi üzerine durumu bir raporla üstlerine bildiren Rawlinson, bizzat Trabzon'a giderek oradaki gelișmeleri de öğrenmek ister. Fakat buna muvaffak olamaz, yalnız 21 Haziran'da General Beach ile görüşmek üzere Kars üzerinden Rus hududuna ulaşır. Burada Tiflis'ten gelen amirini karşılayarak birlikte Erzurum'a dönerler. General Beach 3 Hazira'nda Tiflis'e dönerken, bir mühendis ve istihbarat subayını da Rawlinson'un mahiyetine bırakır. Bir de demiryolu subayı göndereceğini vaadeder. Ayrıca Tiflis'ten malzeme de gönderilmiş, ancak bunlar Ermeni bölgesinden geçerken kaybolmuştur. Ermeniler tarafından yağmalanmıştır ${ }^{32}$.

Trabzon'da kısa bir süre kaldıktan sonra tekrar Erzurum'a dönen Rawlinson, Kazım Karabekir'in, Ermenilerin sınır boyunda taarruza geçtiği yönündeki raporları doğrultusunda, olayı yerinde incelemek üzere gerekli çalışmalara başlar. Bu arada Tiflis üzerinden kendisine ulaşan demir-

bir ruhla kendini tanıtacak bir devlet haline geleceğini kestirmek güç değildir. Okulu gezip gördükten sonra Paşa'yı memleketinin geleceği için güttüğüu aydın politikadan dolayı gayet candan tebrik ettim". Karabekir de, Rawlinson'un okulu gezdikten sonra Londra'ya yazdığı raporda; "kabiliyetsiz saydığımız Türklerin neler yaptığını görmek ve yararlanmak için Erzurum'a çocuk terbiye uzmanları gönderirseniz çok isabet edeceksiniz." dediğini belirtmektedir. Bkz. A. Rawlinson, a.g.e., s. 181 ve K. Karabekir, İstiklal Harbimizin Esasları, İstanbul 1995, s. 30.

31. Mayıs sonunda Trabzon'a bir kıta İngiliz askeri çıktığı haberi istenilen yardımın geldiğine yorulursa da, herhangi bir gelişme olmayınca Rawlinson bizzat sahile gidip durumu öğrenmek ister. Bkz. A. Rawlinson, a.g.e., s. 184.

32. Bu sırada Rawlinson'un beklediği takviye güç ve malzeme de Trabzon'a ulaşmıştır. 8 Temmuz'da bizzat Rawlinson'a teslim edilen takviye güç ve malzeme, 2 istihbarat subayı, 2 tercüman, 8 at, 2 katır, 1 doktor, hastahane nöbetçisi ve ecza techizatı, 2 asteğmen, 20 erden mürekkeptir. Rawlinson burada bir miktar top ve cephane de bulur ve Türklerin kendilerinden silah ve mühimmat kaçırdıkları imasında bulunarak, daha önceden kendilerine verilen listelerin de çok güvenilir olmadığı kanaatini belirtir. Bkz. A. Rawlinson, a.g.e., s. 184. 
yolu subaylarıyla birlikte ekibindeki subay sayısı 10'a ulaşmıştır ${ }^{33}$. Bu s1rada Mustafa Kemal de Erzurum'a gelir ${ }^{34}$.

Erzurum Kongresini dikkatle takip eden Rawlinson, bir ara bunu önleyebilmek için Mustafa Kemal'i tehditkar bu ifadeyle uyarmaya kalkışırsa da dikkate alınmaz ${ }^{35}$. Bu arada Kazım Karabekir Paşa'nın tahsis ettiği bir dekoville Kars'a giden Rawlinson, oradaki Ermeni subayların hazır ol-

33. Aynı dönemde Erzurum'dan İstanbul'a muazzam silah ve mühimmat sevkiyatı yapıldığına dair raporlardan Rawlinson memnun, fakat şüpheli görünür. Erzurum'da Rawlinson'un kafilesine 1916-1917'de Rus ordusuyla bölgedeki harekata katılan bir Rus albayı ve emir subayı da katılmıştır. Rawlinson, Türklerin bildiği fakat ortaya çıkarmadığı silahların bulunmasında bu Ruslardan oldukça faydalandıklarını da kaydeder. Karabekir, ordu kaçaklarından Şamlı Nuri diye birinin de İngilizlere yardımcı olduğundan bahseder. Amerikan istihbarat subayı Teğmen Dunn ve bir Fransız subayı ile Erzurum'da görüşmüşlerdir [Bkz. A. Rawlinson, a.g.e., s. 190]. Karabekir 30 Haziran'da Rawlinson'u ziyaretinde, Rawlinson'un odasında bir Amerikalı subayın bulunduğunu ve şahit olduğu bir diyaloğu, "Bir aralık Rawlinson Amerikalı subayın yan cebine vurarak, Amerikalıların işi ceplerini doldurmaktır dedi. Amerikalı da gayet ciddi olarak, İngilizlerin işi de dünyayı yutmaktır. Burada ne arıyorsunuz dedi." şeklinde anlatır. Bkz. K. Karabekir, İstiklal Harbimiz, s. 59.

34. İngiliz İtilaf Komiseri Mustafa Kemal'in İstanbul'a çağrılmasını Müffetiklerin isteği olarak tespit etmiş ve askerlik rütbesinden mahrum edildiğini yazmıştır. Bkz. A. Rawlinson, a.g.e., s. 190.

35. Bkz. A. Rawlinson, a.g.e., s. 189. Gerçekten de Rawlinson 9 Temmuz'da Mustafa Kemal ile görüşmüş ve Kongre'nin toplanmamasını istemiş, Mustafa Kemal bunu reddetmiştir [Bkz. M. Müfit Kansu, Erzurum'dan Ölümüne Kadar Atatürk’le Beraber I, Ankara, 1966, s. 47]. Bundan sonradır ki Mustafa Kemal Rawlinson'a göre, ezeli düşmanı olan Enver'in evvelce Genç Türk Partisi olan partisini desteklemeyi taahhüt etmiştir. Bu sıralarda Mustafa Kemal'i sık sık gördüğünü ve Erzurum Kongresi çalıșmalarının da farkında olduğunu belirten Rawlinson, Mustafa Kemal'i Kongrenin toplanmaması konusunda tehditkar bir ifadeyle uyarırsa da bu dikkate alınmaz. Burada İttihat ve Terakki ile Mustafa Kemal arasında bir ilişki kurması da sanırım, İttihatçıların gerek Milli Mücadele içindeki çalışmaları, gerek Mütareke sonrası yapılan bazı görüşmeler ve toplantılardan, gerekse Anadolu'da ve yurt dışında mütareke aleyhindeki çalışmaları dolayısıyla olsa gerektir.

Rawlinson Kars bölgesindeki Ermeni mezalimi ile ilgili çok kesin bilgiler almıştır. Kendi ifadesiyle: "Benim adamlarıma yalnız yakaladıkları zaman neler yaptıklarını gördüğüm için neler yapabileceklerini tahmin edebiliyordum. Zivin'den Tiflis'e bir telgraf çekerek, Ermenilere Müslüman halka bağımsız kumanda etmek hakkı verilmemesini insanlık namına rica ettim. Bu Ermenilerin disiplinsiz ve kontrolsüz, devamlı işkenceler yapmalarından bizim sorumlu tutulacağımızı belirttim." dedikten sonra, Tiflis'ten bir İngiliz birliğinin bölgeye gönderildiği ve kendisinin de bu sebeple Sarıkamış'a gitmesinin bildirdiğini belirtir. 28 Temmuz'da Sarıkamış'ta birliği karşılayıp, yapılan işkencelerin delillerini nerede arayacakları hakkında bilgi verir. Sonradan pek çok delil bulunduğunu öğrenmiştir. $\mathrm{Bu}$ delillerden ne o zaman ne de daha sonra hiç bahsedilmemektedir. Bkz. A. Rawlinson, a.g.e., s. 227. 
duğu bir toplantıda, "Ermeni askerlerin Müslümanlara yaptıkları muamele hakkındaki şikayetleri anlattığını, tahmin ettiği gibi birçok gerçekleri inkar edemediklerini nakleder. Türklerin de kendilerine yaptıklarını anlattıklarını, onların şikayetlerinin de Türklerinki kadar esaslı olduğunu kaydeder. Her iki tarafın zarar gördüğü bu ortamda karlı çıkmayı düşünen de Rawlinson'un șahsında bu iki toplum arasına düșmanlık tohumlarını eken, şimdi hakemlik rolüne bürünmüs olan Avrupalılar olmalıydı. Fakat bu tarafı hiç düșünmeden Müttefiklerin himmetleriyle bir vatan ve bir devlet sahibi olmak isteyen Ermeniler, Rawlinson'dan Müslümanları silahsızlandırmasını, bu konuda zor kullanmısını istiyorlar ve Rawlinson'un yardım isteğini de memnuniyetle kabul ediyorlard ${ }^{36}$.

Rawlinson, Kars bölgesini dolaşırken Ermenilerin davetlerini, Kürtler tarafından tarafgirlik olarak yorumlanacağı gerekçesiyle reddeder. Kürtlerle iyi geçinmek ve onlarla içli dışlı olmak niyetindedir. "Kelimenin tam anlamıyla dağ adamıdırlar. Hepsi de hırsız olmakla beraber iyi insanlardır. Dövüşmekten hoşlanırlar." şeklinde tanımladığı Kürtlerle içli dışlı olmak arzusundadır. Evvelce Müttefiklere sempati ile bakan ve İngiliz himayesini kabule gönüllü olan Kürtlerin, Müttefiklerin siyasetleri ve Ermenilerle ilgili davranışları yüzünden Batılı devletlere itimatları sarsılmıştır. Bu da Rawlinson'u üzer. Kürtler, Ermenilerin idaresine verilmeleri ve Avrupa ordularının Ermenileri desteklemeleri gibi bir durumda memleketlerini boşaltarak Türk sınırının ötesine (Türkiye) gideceklerini de Rawlinson'a söylemişlerdir. Aras nehrinin kuzeyinde hakim olan aşiret reisi Ömer Ağa ile yaptığı görüşmede de Rawlinson, Ömer Ağa'nın kendisine; Burada ne bela arıyorsun? Müttefikler ne demeğe bu bölge Ermenilerin olacak diye ilan etmişler? ${ }^{37}$ sorularından sonraki konuşmalardan aynı izlenimi edinmiştir.

36. Rawlinson'un teftiş görevini yapabilmesi ve Ermeni mezalimini yerinde incelemesi için, Kazım Paşa tarafından üç vagonlu Amerikan yapımı bir dekovil treni tahsis edilir. Bu küçük tren için bile yollar muntazam değildir. Aras vadisinde demiryolu kaya düşmesi sonucu kapanmış olduğundan, Rawlinson Kazım Paşa'dan yardım ister. Toplanan silahların yüklendiği trenlerin sevk edilmesi, Zivin'e taşınması ve orada sınırın öbür tarafındaki trenlere yüklenmesi ve Zivin'de hazır trenler bulundurulmasını ister. Rawlinson burada Türklerin tavrını net olarak tespit etme şansının doğduğuna da inanmaktadır. Ya silahlarını teslim etmek, ya da bunu resmen reddetmek durumunda bırakmıştır. Kazım Karabekir'in cevabı da silahları teslimi açıkca red olmasa bile, bu anlama gelen bir cevap olmuştur. Rawlinson demiryolunun tamiri için Ermeni işçi de bulamamıs ve Kars'taki Ermeni karargahına gidip Ermeni askerlerin demir yolunun açılmasında yardımcı olmalarını istemiştir. Bkz. A. Rawlinson, a.g.e., s. 192-196.

37. Bkz. A. Rawlinson, a.g.e., s. 199-213. 
Kars'tan Kağızman, Zivin yoluyla Erzurum'a hareket eden Rawlinson, bölgede gördüklerini; "Türkler tarafından kışkırtılan ve Alman uzmanlarca yetiştirilen Türklerin Gümrü'deki Ermeni muhacirlere saldırmağa hazırlandıkları gerekçesiyle, Tiflis'ten Kars'a bir İngiliz tugayı gönderilerek, Türk halkın yeni bağımsız cumhuriyet için oluşturduğu İslam Parlamentosu (Şura) üyeleri tutuklanarak planları bozuldu. Bu İngiliz tugayının gelişinden sonra Kars'ın Ermenilere bırakıldığı ilan edildi. İngiliz tugayı çekildi ve Ermeni işgali ve işgalle birlikte her türlü zorluk başladı. Ermeniler zorla silahlarını almak gerektiği bahanesiyle Müslüman halkı topyekün soymağa ve onlara zulüm etmeğe başladı. Ovalık bölgede amaçlarına ulaşmışlardı. Dağlık olan Oltu ve Ardahan bölgesinde aşiretlerle karşılaştılar. Bölgenin hakimi Eyüp Paşa idaresinde Ermeni hareketi durduruldu." 38 şeklinde özetler.

Esasen Zivin'de Rawlinson bir sürprizle karşılaşır. Demiryolu subayı ve iki erin beklediği silahla dolu tren eşkıya kılıklı kişiler tarafından sarılmış, subay ve erler bir vagona kapatılarak, katırlar tarafından çekilen bir vagon kervanına silahlanı yükleyip dağa taşımışlar. Sonra subay ve erleri serbest bırakıp, memleketi terk etmelerini istemişler. Kazım Karabekir'den gelen bir mektuptan olaydan haberdar olduğunu, olayın halk tarafından gerçekleştirildiği kanaatinde olduğunu öğrenir. Rawlinson bu numarayı yutmuş görünmekten başka çaresi olmadığını ifade eder ${ }^{39}$. Karabekir bu olayın gerçekte Rawlinson'un düşündüğü gibi bir yanıltma olduğunu kabul eder. Olay sivil kıyafetli askerlerce düzenlenmiş ve halk veya eşkiyalarca gerçekleştirilmiş görüntüsü verilmiştir. Zivin'deki (Taşkesen) Türk subayı Binbaşı Emin Bey de Karabekir'e durumu bu minval üzere rapor etmiștir. Karabekir. uygulamadan gayet memnun olarak olayı Rawlinson dahil ilgili makamlara da rapor eder. Mustafa Kemal'de bilgi verir. Tren gittiği gibi Erzurum'a geri gelmiştir. 27 Temmuz'daki RawlinsonKarabekir görüşmesinde de konu görüşülmüștür. Karabekir bu konunun Rawlinson-Mustafa Kemal görüşmesinde tartışıldığını da kaydeder ${ }^{40}$.

26 Temmuz'da Erzurum'a ulaşan Rawlinson, 27 Temmuz'da Karabekir ile görüşür. Görüşmede Karabekir, Rawlinson'un isteklerine cevap

38. Bkz. A. Rawlinson, a.g.e., s. 215. Kars İslam Şurası'nın sona erdirilmesi ve Cihangiroğlu İbrahim ve bazı parlamenterlerin Malta'ya sürülmesi olayı 12 Nisan 1919 tarihindedir. Bkz. A. Ender Gökdemir, Cenubi Garbi Kafkas Hükümeti, Ankara, 1989, s. 156, Rawlinson olayları kronolojik vermemiş olsa gerek.

39. Bkz. A. Rawlinson, a.g.e., s. 230.

40. K. Karabekir, İstiklal Harbimiz, s. 82 vd., ayrıca bkz. Selahattin Tansel, Mondros'tan Mudanya'ya Kadar II, s. 80. 
verecek durumda olmadığını, Konferans'ın (Erzurum Kongresi) devam ettiğini, memleketin karışık olmasından dolayı, gerekli emirleri verecek konumda olsa bile silahların sınırdan geçirilmesine halkın izin vereceğinin şüpheli olduğunu ileri sürer ${ }^{41}$. Rawlinson da Karabekir'e teşekkür edip durumu Türk telleriyle hükümetine bildirmek için müsaade alır ve acilen İstanbul'daki Başkomutana bildirir ${ }^{42}$. Aynı telgrafı sınırdaki subayı aracılığıyla Tiflis'teki genel karargaha da çekmişti. Rawlinson, Amerika'nın, Türkiye ile Ermeni, Azerbaycan ve Gürcü mandalarını kabul etmesine rağmen, Amerikan Meclisi'nin bunu onaylamaması halinde, herhalde, İngiltere'nin bu mandayı üstleneceğini de söylemiş, ayrıca İngiltere'nin İslam alemine yakınlığı dolayısıyla daha başarılı bir mandater olabileceğini de eklemişti ${ }^{43}$. 28 Temmuz'da Mustafa Kemal ile yararlı bir görüşme yaptığını söyleyen Rawlinson görüşmenin teferruatını vermez. Ancak Mustafa Kemal'in Konferans'ta varılacak son ve resmi kararları kendisine bildireceğine söz verdiğine işaret eder.

5 Ağustos'ta Rawlinson'a verilen cevapta, bütün adamlarını Türk toprakları dışına çıkarması ve kendisinin Kars'ta kalması istenmektedir. Bunun üzerine maiyetine hazırlanmalarını söyleyen İngiliz İtilaf Komiseri, Karabekir'e de adamları için bir tren ayarlaması konusunda ricada bulunur. 6 Ağustos'ta Karabekir ile vedalaşmak üzere Erzurum'a gidip, görüşür, dostça ayrılırlar. Karabekir, bu görüşmede Rawlinson'un, artık Erzurum'da İngiliz kalmayacak, Sarıkamıș veya Kars'ta kalıp Karadeniz'den İran'a kadar sınırı gözleyeceğiz dediğini yazar. Ayrıca Rawlinson'a Kolordu veznesinden muhtelif defalar 1200 lira para verildiğini de kaydeder ${ }^{44}$. Rawlinson, Mustafa Kemali le de üç buçuk saat süren bir görüşme yaptıklarını ve Mustafa Kemal'in kendisine o gün kabul edilen "Milli Misak" hakkında bilgi verdiği ve ertesi gün son şeklini kendisine telleyeceğini vaad ettiğini kaydeder. Rawlinson devamla, bu paktın (Milli Misak) o zaman ilk defa ileri sürüldügüunü ve Milliyetçilerin

41. K. Karabekir, İstiklal Harbimiz, s. 84 vd., Karabekir, Rawlinson'un silah vermeme meselesinde Belediye Reisi ve Müftü'nün de bulunduğu Müdafai Hukuk temsilcilerine gizli olarak "Mustafa Kemal Paşa' yı iskat fikrini söylemişti." şeklinde bir bilgi de veriyor. Bkz. Kazım Karabekir, Enver Paşa ve İttihat ve Terakki Erkanı, İstanbul, 1990, s. 39.

42. Bkz. A. Rawlinson, a.g.e., s. 226. Rawlinson'un teli üzerine, Harbiye Nezareti'ne durumu bildirip, zecri tedbirler alınması konusunda istekte bulunur. Bkz. Harp Tarihi Vesikalar Dergisi, Sayı: 3, Belge 49.

43. K. Karabekir, İstiklal Harbimizin Esasları, s. 50.

44. K. Karabekir, İstiklal Harbimiz, s. 98. 
başlıca ülküsü, bütün politikalarının ve çabalarının amacı olmuştur $\operatorname{der}^{45}$.

7 Ağustos Akşamı Sarıkamış’a ulaşan Rawlinson, Tiflis üzerinden gelen bir telgrafla İstanbul'a çağrılır. 14 Ağustos'ta İstanbul'a varır. Beyoğlu'ndaki genel karargaha gidip Doğu ve Doğu illerindeki durumu etraflıca anlatıp, Milli Misak'ın bir kopyesini Başkomutana verir. Daha sonra memleketin başka taraflarında toplanacak kongrelerde de bu Misak'ın sunulacağı ve muhakkak surette kabul edileceği kanaatindedir ${ }^{46}$. Sivas Kongresi de zaten kararlaştırılmıştır. Yalnız 28 Ağustos'ta Londra'da Harbiye Bakanı ve diğer yetkililerle görüşerek mütalaalarını arz eden Rawlinson'a göre; Doğu bölgesinde Türklerin ordularını terhis ve silahsızlanmadan vazgeçerek Mütareke hükümlerini reddetmeleri hiç de sürpriz sayılmamalıdır. Bu yüzden İngiliz ordularının Kafkaslardan çekilmesini geciktirmeye çalışır ve O'nun uyarısı üzerine Batum'un boşaltılması bir müddet ertelenir. Rawlinson'a göre, raporları ilgiyle karşılanmış ancak, görüşleri ciddiye alınmamıştır ${ }^{47}$.

Lord Curzon'la ikinci defa görüşen Rawlinson, 20 Ekim'de Londra'dan harekele, tekrar İstanbul'a ve oradan da 6 Aralık'ta Trabzon'a ulaşır. Bu defa Erzurum'dan gelen yazı doğrultusunda Bayburt-Gümüşhane güzergahını tercih eder. Rawlinson bu yolculuğun çok zor şartlarda gerçekleştiğinden, kış ve tabiat şartlarının çetinliğinden uzun uzun bahseder. Bayburt'tan sonra arabaları öküzlerle Türk koylülerine çektirilir. Rawlinson çalışmalarını beğenmediği köylüleri taciz eder.

Bayburt'a geldiklerinde bölgenin Rum piskoposu Rawlinson'a ziyarete ve şikayete gelir. Görüşme Rawlinson'un ifadesiyle aynen şöyledir: "Bayburt'a geldiğimizin ertesi günü memleketin Rum piskoposu beni ziyaret edip, komşularına Türklerin kötü muamele yaptıklarından şikayet etti. Fakat somut örnekler vermedi. Kilisenin bu çok sayın ve çok rayihalı direği nihayet sabrımı taşırdı. Kendi ve vatandaşları için yanlış bir görüşü savunduğu aşikardı ve pis kokuyordu. Bu bölge Rum imiş. Türkler de sır-

45. Bkz. A. Rawlinson, a.g.e., s. 231 vd., Sonyel, Mustafa Kemal-Rawlinson görüşmesinin iki saat sürdüğünü ve Mustafa Kemal'in Bolşevik eğilimini ve Enver Paşa ile işbirliğini reddettiğini, ancak Rawlinson'un buna inanmadığını yazar [Bkz. S.R. Sonyel, Türk Kurtuluş Savașı ve Dış Politika I, Ankara, 1987, s. 106] ve ayrıca, Salahi R. Sonyel, "1919 Yılı İngiliz Belgelerinin Işı̆ı̆ında Mustafa Kemal ve Milli Mukavemet”, Türk Kültürü, Yıl: 1969, Sayi: 85, s. 46.

46. Bkz. A. Rawlinson, a.g.e., s. 234.

47. Bkz. A. Rawlinson, a.g.e., s. 249 vd. 
naşarak buraya sokulmuşlar, gibi sözler söylüyor, durumun tam tersi olduğunu anlamıyordu. Piskopos, Amerikan milleti insanlığı ve hayırseverliği ile birçok Rum'u ölümden kurtardı diye, şimdi de ister mantıklı, ister mantıksız bütün isteklerinin desteklenmesini istiyordu. Bu sebeple, vatandaşlarının Türklerin memleketinde ve Türk Hükümeti'nin vatandaşı olduklarını, mensup oldukları milletin Türklerle savaş halindeyken esir kamplarına kapatılmadıklarına şükretmelerini söyleyip savdım. Daha sonra sahil boyunca bütün Rum gazeteleri benim memleketime layık olmayan bir temsilci olduğumu ve Çarmı gerilmesem bile rütbe tenziline gidilerek cezalandırılmam gerektiğini yazmışlar" ${ }^{48}$. Karabekir, Rawlinson'un Bayburt'ta bir mühendisle maden araması ve şimendifer yapılması gereken yollar hakkında dolaşmış olduğu ve Miralay Rüştü ile görüşüp, Karabekir ve Mustafa Kemal ile görüşme isteğinde bulunduğu haberini aldığını da kaydeder ${ }^{49}$.

26 Aralık'ta Erzurum'a ulaşan Rawlinson grubuna bu defa eskiden İran konsolosluğu olan bir ev tahsis edilmiştir. Kazım Karabekir ile görüşüp, konuşurlar. Almış olduğu askeri ve resmi emirleri Karabekir'e bildiren Rawlinson, Mustafa Kemal ile görüşmek isteğini Karabekir'e de be$\operatorname{lirtir}^{50}$. Mustafa Kemal'in Ankara'ya gittiğini, bu mevsimde Ankara'ya gitmenin hava şartları sebebiyle mümkün olmadığını söyleyen Karabekir, Müttefikler ve özellikle İngiltere ile dostluk kurmayı daha çok istediklerini açıklar ${ }^{51}$. Rawlinson Karabekir'e, Bayrut'ta Rum Piskoposu ile görüşmesini de; Karabekir'e, "Burası Türkiye'dir, defolun Yunanistan'a Selametiniz için başka çare ve Pontus falan da yoktur dedim." şeklinde anlatır.

Rawlinson, 2 Mart'ta Türk makamlarının izni ve yardımı ile iki şoför, iki makineli tüfekçi ile asteğmeni kızaklarla sahile gönderir ve kendisi de her an hareket edecek şekilde hazırlanır. 16 Mart gecesi, yani tutuk-

48. Bkz. A. Rawlinson, a.g.e., s. 269-270.

49. K. Karabekir, İstiklal Harbimiz, s. 377 vd.

50. Karabekir, Mustafa Kemal'in Ankara'ya gittiğini, burada Milli Hükümet'in merkezini kurmakta olduğunu, isteğini kendisine bildireceğini söyler. Rawlinson'un bu görüşmedeki izlenimleri; Karabekir, memleketine teklif edilecek barıș şartlarının Türk milletinin görüşlerinden çok uzak, İstanbul ve Müttefikler arasında belirlenen prensipler olarak dikte ettirilmeye çalışılacağından endişeliydi. Kendisine hak verdim ama belli etmedim. Bu sonuçları görebildiğine de hayret ettim. şeklindedir. Bkz. A. Rawlinson, a.g.e., s. 283.

51. Görüşmeden sonra Karabekir, Mustafa Kemal'e Rawlinson'un görüşme isteğini iletir. Ankara'dan, Rawlinson'un ancak resmi ve yetkili olması durumunda kendisiyle görüşülebileceği cevabı verilir. Bkz. K. Karabekir, İstiklal Harbimiz, s. 384 vd. ayrıca yazışmalar için bkz., Atatürk'ün Milli Dış Politikası I, Ankara, 1981, s. 148-151. 
landığı gece Rawlinson, memlekette yeni yollarla demiryollarını ve savaş içinde yapılan diğer ulaştırma sistemlerini gösteren en son haritalardan biri üzerinde çalıșmış, sonra karısına mektup yazmaya başlamış idi. Heyecandan Karabekir'e yazdı ̆̆ı pusula için bu mektup kağıdını kullanmıștır. Heyecanının sebebi de dökümanlarını imha etmek için zaman kazanmaktır ve bunu başarmıștır ${ }^{52}$.

Rawlinson, hapishanede bir Türk subayından Sevr Andlaşması'nın imzalandığını öğrenir ve Ermenilere Doğu Anadolu'da toprak verilmesini sonuçlarından endişelidir. Ancak kendilerinin, Müttefik Yüksek Konseyi'nin Doğu Anadolu'da belirli kesimleri Ermenilere vermesini kararlaştırmasının tamamıyla faydasız olduğunu anlayacak durumda bulunduklarını, doğacak dehşetli neticeyi tahmin edebildeklerini ve o zamandan itibaren Türklerde taarruz için devamlı hazırlık belirtileri görüldügüünü ifade eder" 53 . Yine İtilaf Komiseri Rawlinson'un ifadelerine göre; Müttefiklerin bu işlerle uğraştığı dönemlerde, 26 Mayıs 1920'de bir Bolşevik heyeti Ankara'ya gitmek üzere Erzurum'dan geçmiş, 27 Mayıs'ta penceresinden üniformalı bir Alman subayı görmüştür ${ }^{54}$. Bu konuda başka bir yerde herhangi bir kayıt bulunmamaktadır. Dolayısıyla bu bilgilerin doğruluğu şüphelidir. Haziran başlarında askeri hazırlık faaliyetleri ve asker yazılarak gelenlerin sayısının artması da Rawlinson'un dikkatini çeker. Barış şartları duyulduğunda Erzurum'da herkesin bunlara alaylı kahkahalarla güldügü tespiti de Rawlinson'a aittir ${ }^{55}$.

52. Rawlinson, Rauf Bey ve arkadaşlarının tutuklanması ve Malta'ya sürgün edilmesine karşılık rehin alınmıștı. Burada bahsedilen Albay, Erzurum Mevki-i Müstahkem Kumandanı Kazım Dirik'tir ve Kolordu'ya verdiği rapora göre, Rawlinson İngiliz bayrağını güvenlik nedeniyle kendiliğinden indirmiştir. Bkz. Tarih Vesikaları Dergisi, Sayı: 26, Belge: 663, Bkz. A. Rawlinson, a.g.e., s. 287-291. Ayrıca tutuklama için bkz. Kazım Karabekir, İstiklal Harbimizin Esasları, s. 62 ve ayrıca K. Karabekir, İstiklal Harbimiz, s. $500 \mathrm{vd}$.

53. Bkz. A. Rawlinson, a.g.e., s. 295. Bu sıralarda Kazım Karabekir bir taraftan Ermenilere karşı celallenen Kürt aşiretlerini teskin etmeye çalışırken diğer taraftan Ermeni zulmünü durdurmaya yönelik harekat için Doğu'da seferberlik ilanına gitmiştir. Rawlinson'un bahsettiği teyakkuz hali budur. Bkz. Selahattin Tansel, Mondros'tan Mudanya'ya Kadar III, s. 235, ayrıca Türk İstiklal Harbi III, Doğu Cephesi, s. 85, Genelkurmay Başkanlı̆̆ı.

54. Bkz. A. Rawlinson, a.g.e., s. 295.

55. Bu sırada Rawlinson'dan otomobiller istenmiştir. Rawlinson otomobillerin ordu için istendiği kanaatiyle, karşı koyamayacağını ancak vermeye gönüllü olmadığını belirtir. Sonrasında da bujilerini ve kablolarını sökerek çalışamaz hale getirir. Otomobiller aygırlarla çekilip. İrlandalı şoför Mahoney'in yardımıyla tamire çalışılır. Daha sonra saklanan parçalar bulunur ve Rawlinson, Mahoney'in de serbest kalması üzerine O'nu ihanetle 
İngiliz İtilaf Komiseri Rawlinson'un çok iddialı, dikkat çekici tespitleri içinde, "Ağustos başında ilk Bolşevik askerleri gelmeye başladı. Şereflerine kasabada büyük gösteriler düzenlendi. Meşalelerle nümayişler ve geçit resimleri yapıldı. Aynı zamanda Türk subayları üniformalarına Bolşevik rütbe işaretlerini kabul ettiler. Hepsi en azından o an için "yoldaş" oldular. Yine bu sırada Rus subaylarına aylıkları Rus altını ile veriliyordu. Bu sıralarda Erzurum'da 10 Rublelik Rus altın parası umumileşti" ${ }^{56}$. S eklinde yer alanlar gerçekten hayret verici iddialardır. Bu tespitler, ya Rawlinson'un esaret hayatı içindeki hezeyanları, ya da Türkleri Bolşeviklere kaptırma endişesi içindeki telaş ile Türk ve Rus üniformalarını karıştırıyor olmasının sonucu olmalıdır. Özellikle Kazım Karabekir'in Bolşeviklerle ilgili yaklaşım ve tavırlarını bilerek, Enver Paşa'nın bir miktar kuvvetle Anadolu'ya girmesine izin verilmediğini dikkate alarak meseleye baktığımızda da bu iddiaların doğru olamayacağı kanaati güçlenmektedir ${ }^{57}$. Ancak o günkü şartlarda Türk insanı içinde Sovyetleri

suçlayıp, İstanbul'a bildirir ve daha sonra cezalandırıldığını öğrenip memnuniyetini bildirir. Bkz. A. Rawlinson, a.g.e., s. 295.

56. Rawlinson 1920 yılı sonlarına doğru açlık çektiklerinden ve tayinlerin askerlerce bölündüğünden, et yiyemediklerinden, kara ekmeklerin sağlıklarını bozduğundan bahseder ve Türklerle ilgili üslubu da değișmeye bașlar. 1921 Noel kutlaması sırasında İngiliz milli marşını söyledikleri sırada, muhafızların ne olup bittiğini öğrenmek için bakışlarını şöyle ifade ediyor: "Bunun üzerine duvardaki delikler, kapıdaki çatlaklar yavaş yavaş pis, Türk, aşağılık yüzlerle doldu" [Bkz. A. Rawlinson, a.g.e., s. 303]. 2 Ocak'ta Trabzon'daki Amerikan Yardım Teşkilatı tarafından gönderilen bir kutu alırlar. Kutuda Hediye ve Noel kutlama mektubu vardır. Rawlinson, 1922 yılı 1 Şubatı'nda tutuklu bulundukları evden genel hapishaneye götürüldüklerini ve 16 Mart 1921'den beri, 10.5 aydır ilk defa dört duvar dışına çıktıklarını yazıyor. Buradaki tarihler de bir yıl ilerden gidiyor. Doğrusu, 16 Mart 1920 ve 1 Şubat 1921 olmalıdır.

57. Esasen bu sırada hapishaneye nakledilen ve adi suçlularla bir arada kalmayı hazmedemeyen Rawlinson, hükümetine de sitemkar eleştiriler yöneltir. "Ordularımızın her tarafta muzaffer olduğu ve İngiliz üniformasına dünyanın her memleketinde saygı gösterildiği 28 ay gibi kısa bir zaman öncesine göre memleketimin prestijinin, bu değer biçilmez hazineyi emanet alanların düşüncelerindeki kararsızlık yüzünden zaafa kapılmaları üzerine, ne müthiş bir surette düștüğünü bu çıplak hakikat bana acı bir șekilde anlattı. Șimdi, belki de ört bas edilmesi veya göz yumulması mukadder olan böyle bir hareketin, eski günlerde cezası ne olurdu diye acı acı düşümdüm." diyen Rawlinson, şüphesiz saygı görmek isteyenlerin saygı göstermek zorunda olduklarını da düșünebilecektir. Bu durumlara biraz da Çanakkale'de kırılan onurlarını tamir için, Rawlinson'un da daha önce belirttiği gibi gülünç ve mesnetsiz amaçlarla yola çıkmaları sebep olmuștu. Ama Rawlinson hala bu psikolojiden kurtulabilmiş değildir ve üzüntüsünün kendisi değil, "cahil Asyalıların" gözünde küçük düşürülen memleketi için olduğunu söyler. Rawlinson hapishane komutanı Selahattin Bey ile dostluk kurup eşyalarını pazarda sattırarak yiyecek aldığını, bir süre sonra bir adamının muhafızla çarşıya çıkıp alışveriş yapmasına izin verildiğini söyler. Se- 
ve Sovyetleşmeyi kurtuluş veya onun aracı olarak görenler de az değildi.

Hapishanede bir ara kaçırılmak istendiğini de kaydeden Rawlinson'a böyle bir teklifi gönderen kişi, "Türk kanı içmek için Bolşevik birlikleri toplayan" bir Ermenidir ${ }^{58}$. Rawlinson hapishanede bulunduğu sırada Bölge Komutanı Selahattin de kendisine birtakım istemiyorlard ${ }^{59}$. Yollarda Ermeni ve Rumlar yoktu. Öyleyse öldürülmüşler veya göçe zorlanmış$\operatorname{lard}_{1}{ }^{60}$. Rawlinson daha önceleri Ermenilerin Müslümanlara zulmünden de bahsedip, Rumların silahlı isyan halinde olduklarını ve hatta kendilerini kaçıracakları ümidini taşıdığını kaydetmesine rağmen, bu aşamada onları unutmuş görünmektedir. Birilerine yardım yaparken başkalarının yok olması, anlaşılan Batıyı ilgilendirmiyordu ${ }^{61}$.

Rawlinson, hapishanenin bazı odalarının Türk subayların konaklamasına ayrıldığını ve doğudan gelen bazı subayların kendi görüşlerini

lahattin Bey ile her gün görüşmüş, O'na meraklı olduğu İngilizce'yi öğrenmesinde yardımcı olmuştur. Eleşkirt'in Zilanlı Aşireti'nden Hüseyin Paşa adında bir Kürt paşası da, Rawlinson'a göre Müttefiklerle iyi ilişkiler içinde bulunmasından dolayı hapiste bulunmaktadır. Bkz. A. Rawlinson, a.g.e., s. 306 vd.

58. Bu sıralarda çarşıya çıkan İngiliz, Rawlinson'a bir mektup getirir. Bu mektupta, Rawlinson ve adamlarının kaçırılması konusunda yardım teklif edilir. Rawlinson tanımadığı muhatabın bir Ermeni olduğundan emindir, ancak temkinli hareket eder. Aynı Rawlinson daha sonra, Kars'ta esir edilen 9 bin Ermeni'den sadece 900 'ünün sağ kaldığını da istatistik kaynağının ne olduğunu vermemesine rağmen söylemektedir. Bu mektuplaşma işi devam eder. Atlar bile alınır. Daha doğrusu kimliği bilinmeyen kurtarıcının ifadesi budur. Bu yazışmadan hapishanede de bir ajan olduğu anlaşılmaktadır. Bkz. A. Rawlinson, a.g.e., s. 308-312.

59. Aynı dönemlerde Amerikan basınında konuyla ilgili bir haber yer alır. Haber. "Tutukluluk hali devam eden İngiliz esirlerine kötü davranılmakta, Bolşevik gemilerinin rahatlıkla giriş çıktığı Anadolu limanlarına İngiliz ticaret gemileri sokulmamaktadır" [Bkz. Osman Ulagay, Amerikan Basınında Türk Kurtuluş Savaşı, İstanbul 1974, The New York Times 1 Haziran 1921]. Bu gibi haberler Amerikan Yardım Teşkilatı üyelerince Amerika'ya ulaştırılıyor olsa gerekti. Amerikalılar, İngilizlerle görüşüp konuşmasalar bile durumdan vazife çıkarmış olmalıydılar.

60. Bkz. A. Rawlinson, a.g.e., s. 334-335.

61. 24 Nisan'da Rawlinson ve grubu Erzurum'a döner. Hapishanede parasını birkaç parçaya bölüp saklar. Bu paranın aranması ve bulunamaması da Rawlinson'a büyük keyif verir. "Türkler kafaca zayıf olduklarından parayı bulamadılar" der. Hapishanede Ermeni esirler arasında bulunan bir Bulgar subayıyla elindeki Türkçe-Fransızca sözlük aracılığıyla, şifreli olarak anlaşan Rawlinson, yakında serbest bırakılacak olan bu subayla İstanbul'a götürmesi için, muhafızları atlatarak bir mektup vermeyi başarır ve Bulgar için de, İngilizler emrinde kendisine iş verilmesi ve kendisinden yararlanılması konusunda tavassutta bulunur. Bkz. A. Rawlinson, a.g.e., s. 337. 
Müttefiklere iletmek için kendisini bir kanal olarak kullanmak ve Rauf Bey ile mübadele etmek amaciyla kendisini ziyaret ettiklerini yazar ${ }^{62}$. İngiliz Albay Rawlinson'un gizli ve misyonu da buydu. Demik ki taraflar birbirlerini anlıyorlardı.

2 Ekim'de Rawlinson'a mübadele edilmek üzere 5 Ekim'de Trabzon'a hareket edileceği haberi verildikten sonra, 14 Ekim'de Trabzon'a gelen kafile Rum dolu Madam Kosvekis'in evine yerleştirilmiş, 31 Ekim öğleden sonra limana gelen bir İngiliz zırhlısı ile İnebolu'ya götürülen Rawlinson ve grubu, 1 Kasım 1921 tarihinde mübadele edilmiştir63.

Rawlinson serbest kaldıktan sonraki mütalaasında biraz daha mantık$l_{1}$ ve esaret hayatının duygusallığından arınmış görünmektedir. "O zaman beslediğim, hala da beslemekte olduğum kanaatçe, Türkiye ile dostane münasebetler kurmak, eğer mümkünse memleketimizin esaslı politikası olmalıdır. Bizim çektiklerimizin Türk aleyhtarı bir partinin elinde bir silah olarak kullanılmasına müsaade etmemek niyetindeydim. Kaldı ki; bize yapılan muamelenin küçük subayların cahilliğinin ve görevlerini ihmal etmemelerinin sonucu olduğuna inanıyordum. Münferit ihmalleri ele alarak umumi efkarı bütün bir millete karşı ayaklandıracak yerde, bütün mesele daha geniş bir görüşle incelenmelidir. Yine ne Türklerin kötü muamele etmesinde, ne de Türk idaresi altındaki birçok bölgelerde çok uzun yıllardan beri Hıristiyanlara yapılan mezalimde bir yenilik yoktu. Bu meselelerdeki kargaşalığı yalnız gösteri ile değil, icabında ciddi ve askeri bir harekatın takip edebileceği zor kullanarak desteklenmeğe muktedir olmadıkça meseleleri öne sürmek son derece tedbirsizlik olurdu ${ }^{64}$.

62. Bkz. A. Rawlinson, a.g.e., s. 345. Demetre Vaka adındaki Amerikalı gazetecinin Dr. Cevdet ile yaptığı ve Asia dergisinin Mart 1922 sayısında yayınlanan röportajda bazı şahısların bahsedilen bölgelere gönderildiğinden bahseder. Dr. Cevdet Ulagay'a göre Abdullah Cevdet'tir. Bkz. Osman Ulagay, a.g.e., s. 171,

63. Mübadele konusunda geniş bilgi için bkz. Rahmi Doğanay, "Milli Mücadele'de Türk-İngiliz Esir Değişimi”, F.Ü. Sosyal Bilimler Dergisi, C. 10, Sayı: 1, Elazı̆̆, 2000, ayrıca Bilal N. Şimşir. Malta Sürgünleri, Ankara 1985.

64. Bkz. A. Rawlinson, a.g.e., s. 363. Rawlinson, bütün nezaketine rağmen Doğu'da Hıristiyanlara zulüm yapıldığı imasını yapmaktan kendini alamıyor. Bu iddiaların tarihi seyri bir tarafa, Milli Mücadele yıllarında ve özellikle Ermenilerle ilgili durum hakkında, Rawlinson'un da büyük bir hayranlıkla faaliyetlerinden bahsettiği ve tarafsız Amerikan müşahitleri olarak değerlendirdiği Amerikan Yakın Doğu Yardım Kurumu temsilcisi Amerikalılar, 1920 yılı sonlarında gerçekleşen XV. Kolordu harekatı sırasında Ermenilerle ilgili olarak Amiral Bristol'e; "Kars'taki Amerikalıların hepsi iyi ve Türk ordusu bize mükemmel ilgi ve ihtimam gösteriyor. Kars'taki Ermenilere karşı en ufak bir tecavüzde bulunulmamıştır. Teşkilatı önceki gibi devam ettirmeye iznimiz var. Türk Askeri çok di- 
Sonuç olarak; Rawlinson'un gezip, gördüğü bölgelerde ekonomik ve iktisadi sıkıntılar yaşanmaktadır. Bölgede savaş, mücadele, fakirlik vardır. Bunların genel sebebi siyasi kargaşadır. Uzun süren savaşlar ve siyasi otorite boşluğu yanında, buralardaki cemaatler arasındaki hakimiyet ve paylaşım savaşları, sömürgecilerin bu mücadelelere müdahil olmaları bu sonucu getirmiştir. Bölgede Yollar, köprüler bozuk ve yıkıktır. Bayındırlık açısından ilkelik hakimdir. Ermenilerin, Rumların ve hatta Çarcı Rusların yaşadığg sefaletten bahsedilirken, Türklerin, Müslümanların ve kendilerine yakın görmedikleri cemaatlerin durumlarıyla ilgilenmezler. Aynı sefalet herkes için geçerliyken, Amerika'dan Ermenilerin ve Hıristiyanların imdadına koşulur. Müttefiklerin, buradaki sefaletin daha da ağırlaşmasındaki sorumluluklarını bizzat Rawlinson dile getirmiştir.

Siyasi durum çok daha vahimdir. Herkes kendi hesabı peşinde her fırsatı değerlendirmeye yönelik çabalar içinde, ayrıca büyük devletleri de kendi lehine olayın içine çekmeye çalışmaktadır. Müttefikler ve özellikle İngiltere, bölgedeki siyasi cemaatleri kendi çıkarları için kullanmakta ve diğer güç odakları aleyhine kışkırtmaktadır. Bolşevikler ve Türkler, Avrupa ve kısmen de Amerika'nın kurmak istediği düzenin engelleri olarak görülürler. Bunlara karşı Ermeni, Kürt, Gürcü gibi etnik unsurlar yanında, Türk, Rus muhalifleri de kullanmak istemekte, veya muhalifler oluşturmaya çalışmaktadırlar.

Avrupalı büyük devletler güya bölgede asayişi ve düzeni kurmak isterken, yeni ve büyük haksızlıkların ve kavgaların kaynağı olmuşlardır. İttihatçılar, Bolşevikler, Kürtler, Ermeniler, Gürcüler, Menşevikler, Amerikalılar ve Müttefikler, her biri bölgede bir şeyler peşindedir. Türk ve Müslümanların iş birliği, Müttefiklerin Hıristiyanlara destek çıkması ve bir kısım toprak talepleri ile de olsa sağlanmıştır. Ermeni ve Rum iddiaları ve bunlara verilen destek, Müslümanların iş birliğinde etkili olmakla birlikte, özellikle İngiltere Müslümanlanı gözden çıkarmış değil, onları kendi çıkarına organize etmek çabasındadır.

siplinli ve herhangi bir katliam olmadı.” diye yazmıștı. Bkz. Kazım Karabekir, İstiklal Harbimizin Esasları, s. 286. 